\title{
投稿論文
}

\section{加齢黄斑変性症の視力評価における 小数視力表とlogMAR表の比較}

加納 真衣 ·南谷由美子 ·高村 佳弘 - 久保 江理 - 赤木 好男

福井大学医学部附属病院眼科

\section{Comparison of Visual Acuities Measured by Decimal and logMAR Charts in Patients With Age-Related Macular Degeneration}

\author{
Mai Kanou, Yumiko Minamidani, Yoshihiro Takamura, \\ Eri Kubo and Yoshio Akagi
}

Department of Ophthalmology, University of Fukui

要 約

目的：加齢黄斑変性症を有する患者での小数視力表と logMAR (logarithm of the minimum angle of resolusion）表との視力評価に扔ける差異を評価すること。

対象及び方法：加齢黄斑変性と診断された症例58名60眼を対象とし、小数視力表と $\log M A R$ 表そ れぞれで視力を計測した。小数視力表で得た測定值はlogMARに変換後、 logMAR表で得た $\log M A R$ 值と比較した。両検查の結果の差の要因として、年齢、等価球面度数との関連性を相関解析にて分 析した。

結果：60眼のうち、29眼（48.3\%） は小数視力表の視力值と比較して $\log \mathrm{MAR}$ 表の視力值は低下し た。両検查で得た視力值の差との間に、年齢、等価球面度数に関しては有意な相関関係はなかった。 小数視力の值が良いほど、有意にlogMAR表で得た視力值は悪かった。

結論：加齢黄斑変性症の患者での視力評価において、比較的良好な視力域では小数視力表と $\log \mathrm{MAR}$ 表の結果に差が出やすい。これは字詰まり効果によるものと考えられ、この事項は臨床検 査において注意すべき点と思われる。

別冊請求先（910-1193）福井県吉田郡永平寺町松岡下合月 $23-3$

福井大学 医学部 眼科学教室

Tel. 0776 (61) 8403 Fax. 0776 (61) 8131

Key words： $\log$ MAR、小数視力、加齢黄斑変性症、字詰まり効果

$\log$ MAR visual acuity, decimal visual acuity, age-related macular degeneration, crowding effects 


\begin{abstract}
Purpose: The purpose of this study was to investigate the difference between the visual acuities (VAs) measured by the conventional decimal visual acuity (VA) chart and the logMAR (logarithm of the minimum angle of resolution) chart in patients with age-related macular degeneration (AMD).

Subjects and Methods: VAs measured by the decimal and logMAR VA charts were obtained from 60 eyes of 58 patients who were diagnosed as AMD. VA using the decimal chart was converted to the logMAR VA and compared to the obtained logMAR value. The correlations of the VA difference between both methods with patient's age and spheral equivalent were also analyzed statistically using simple regression and correlation analysis.

Results: Twenty-nine eyes of 60 eyes (48.3\%) showed worse visual acuity in the measurements using logMAR chart in comparison to that of decimal visual acuity chart. We found no significant relation between the differences of visual acuity obtained by the two methods and age or equivalent value. However, as the decimal visual acuity was relatively good, the visual acuity measured by logMAR chart showed decreased value significantly.

Conclusion: AMD patients with better VA tended to show a greater difference between the VAs obtained by the decimal and logMAR charts. This phenomenon may be resulted from crowding effects and should be carefully considered in clinical examinations.
\end{abstract}

\section{I . 緒 言}

対数視力 (Logarithm of the minimum angle of resolution ; 以下 $\log M A R)$ 表は、従来の小数 視力表と異なり、視標サイズにおいて視標間 隔・列幅が異なり、一行の視標の数が一定とな っているチャートが標準となっている11,2)。 $\log$ MARは、統計処理においても有利であり、 欧米のみならず本邦においても広く使用され始 めている ${ }^{3)}$ 。単に小数視力值を換算して $\log M A R$ 值にしている場合もあるが、直接 $\log M A R$ 表を 使って測定した視力值とは異なった結果となる ことも少なくない3)。 log MAR表は、文字間隔 が文字サイズに合わせて等間隔に配列されてお $り^{3)}$ 、小数視力で 0.1 から 0.3 にかけ小数視力表 と比較して細分化されているので、ロービジョ ン者の視力評価にも有利な可能性がある。

加齢黄斑変性症は高度の視力低下や変視症を もたらす難治性の疾患である。しかし、抗血管 新生増殖因子 (VEGF) 療法や光線力学的療法 （PDT）など比較的新しい治療法の良好な効果 が多数報告され、その視機能判定は今後ますま す重要性を増してくると考えられる 我々は加齢黄斑変性と診断された患者を対象に $\log \mathrm{MAR}$ 表を用いて視力評価を行い、その有用 性について検討した。

\section{II. 対象および方法}

対象は加齢黄斑変性症と診断された症例58名 60眼（男性28名、女性30名）を対象とした。平 均年齢（ \pm 標準偏差）は70.7 \pm 9.29 歳（51歳～88 歳）であった。加齢黄斑変性症の診断は90Dレ ンズおよび精密細隙灯を用いた眼底観察とフル オレスセインおよびインドシアニングリーンを 用いた蛍光眼底撮影に基づいて行った。補助診 断として網膜光干渉断層計 (Sirrus HD-OCT、 Carl Zeiss社）を用いた。LOCS III（The lens Opacities Classification System III） 分類 ${ }^{5)}$ で 皮質、核、後囊下混濁いずれかでgrade 4以上 の高度な白内障を有する症例は除外した。また、 水晶体再建術などの内眼手術の手術歴のある症 例も除外した。

$\log M A R$ 表はナイツ社製視力表（対数視力検 查装置LVC-1、平均輝度 $\left.230 \mathrm{~cd} / \mathrm{m}^{2}\right)$ を、小数視 力表は夕カギ社製視力表 (MT-366 AC、平均輝 度 $\left.400 \mathrm{~cd} / \mathrm{m}^{2}\right)$ を用いた。この $\log \mathrm{MAR}$ 表は、視 標サイズが小さくなるにつれ、互いの横の間隔 


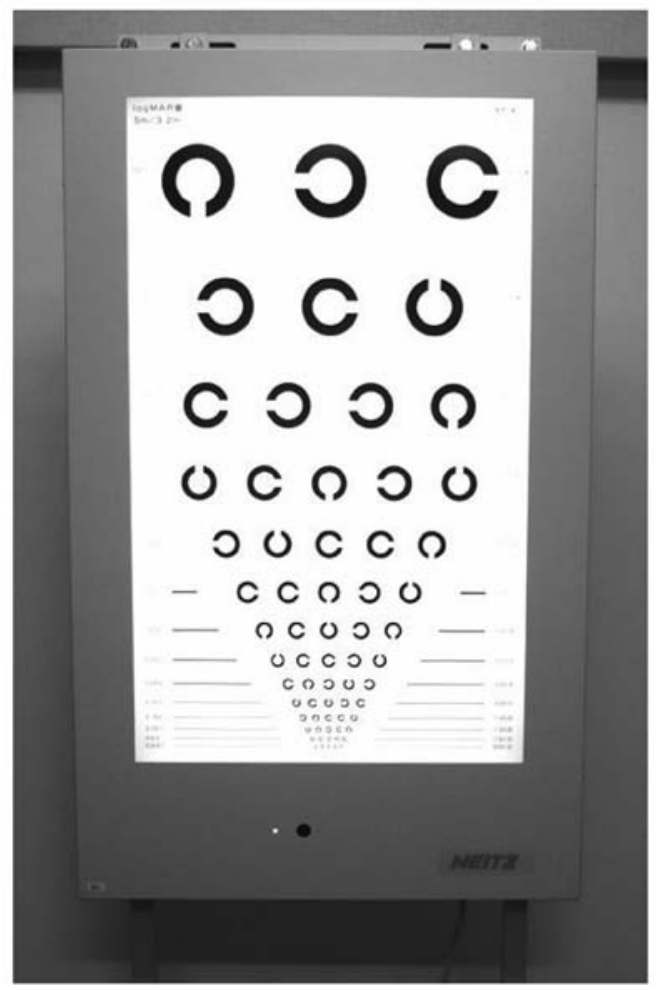

図 1 ナイッLVS-1 の外観

も狭くなっている（図 1 )。いずれの視力検查 も視標までの距離は $5 \mathrm{~m} て ゙ 、$ 明室にて測定した。 視力検查の順はat randomで両者とも連続して 行った。同じ大きさの視標の $50 \%$ を超えて視認 できる場合にその視力值と認めた。検査は単独 の視能訓練士が行った。またlogMAR表のみで 存在する $0.12 、 0.15 、 0.25$ は両視力表が共通して 持っている低い方の值（0.1ないし0.2）に置き換 えた。同様に、小数視力で得た $0.7 、 0.9$ は対数刻 みに無いので、それぞれ0.6、0.8に置き換えた。 各パラメータの関係性は単純回帰解析とピアソ ンの相関分析を用いて行い、 $\mathrm{P}<0.05$ で有意差有 りと判定した。小数視力表で得た視力值は、一 旦 $\log$ MAR值に変換した後、 $\log M A R$ 表で得た 值との相関関係を解析した。

\section{III. 結果}

個々の症例において $\log M A R$ 表から得られた $\log \mathrm{MAR}$ 值と小数視力表で得た視力を $\log M A R$
変換した值との分布を図 2 に示す。60眼のうち、 29眼（48.3\%） は小数視力表の視力值と比較して $\log \mathrm{MAR}$ 表の視力值は低下し、31眼（51.7\%）に おいて不変であった。次に小数視力表で得た視 力を $\log \mathrm{MAR}$ 変換した值と、 $\log \mathrm{MAR}$ 表の logMAR值とを対応のあるstudent's t-testにて比 較した。全体として、 $\log M A R$ 表の方が、小数 視力表より有意に低い視力值を呈した（ $\mathrm{p}<$ 0.0001）（図 3 ）。両者の関連性を単回㷌解析し た所、図 2 において実直線で示した通り有意な 回帰直線が引かれ $\left(\mathrm{Y}=0.23+0.813 \mathrm{X} ; \mathrm{R}^{2}=0.812\right.$ 、 $\mathrm{p}<0.0001)$ 、高視力域ほどlogMAR表での值が 低い傾向が見られた。

続いて、 $\log \mathrm{MAR}$ 表の方が小数視力と比べ低 下した要因を検討した。まず、小数視力表で得 られた測定值をlogMARに変換し、 logMAR表 で得られた $\log M A R$ 值との差を算出した。次い で、異なった視力検査法によって得られた測定 值の差と、患者の年齢、等価球面度数との相関 関係をピアソンの相関係数の検定にて解析した。 まず、患者の年齢との間には、有意な相関関係 はなかった（図 4、 $\mathrm{P}=0.62 ） 。$ 次に等価球面度 数との間の相関関係を解析したが、有意ではな

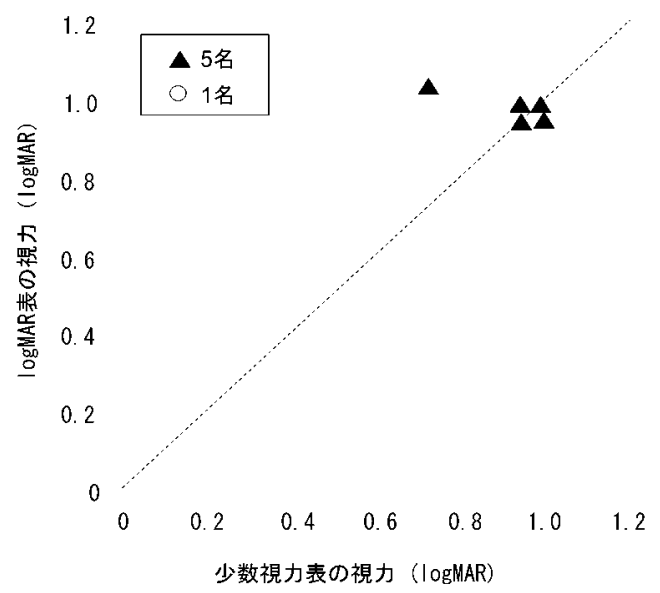

図 2 小数視力表の $\log \mathrm{MAR}$ 変換值と $\log \mathrm{MAR}$ 表の $\log \mathrm{MAR}$ 值との比較

従来の小数視力表で測定した小数視力值を $\log$ MAR変換した值と、 $\log \mathrm{MAR}$ 表で測定した 視力值との関係を示す。○は 1 眼、ムは 5 眼 を表している。点線は、それぞれの值が等し い点の集合を示している。直線は、単回帰直 線を示している。縦軸の上方に、また横軸の 右方に向かうほど視力が悪くなる。 


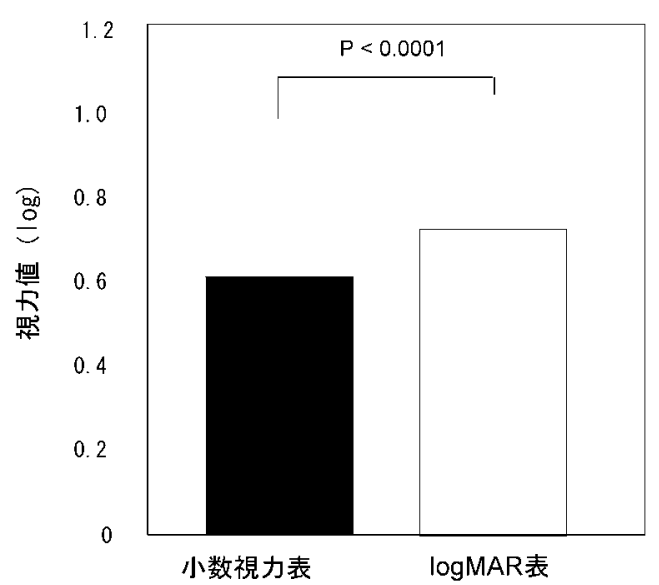

図 3 小数視力表の $\log M A R$ 換算值と $\log M A R$ 表で得 た $\log M A R$ 值の比較

従来の小数視力表で測定した小数視力值を $\log$ MAR変換した值（黒バー）と、 logMAR表 で測定した視力值（白バー）を比較した。有 意な差があった。（Student's t-test, $\mathrm{p}<0.0001$ ) 縦軸の上方に向かうほど視力が悪くなる。

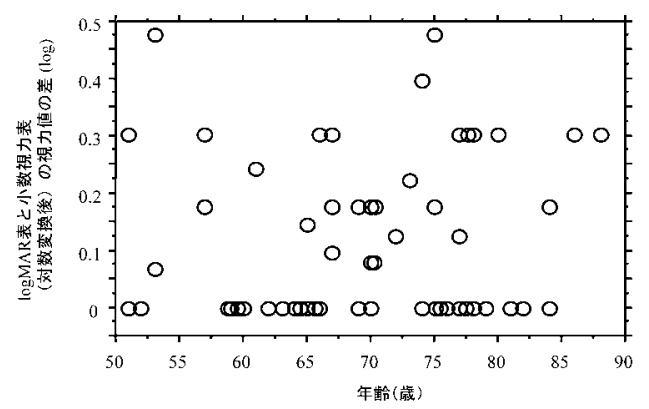

図 4 年齢と視力測定結果の差との相関関係 小数視力表の $\log M A R$ 換算值と $\log M A R$ 表で得 た $\log$ MAR值との差を算出し、年齢との相関関 係の評価をピアソンの相関解析にて行った。 $\mathrm{P}$ $=0.62$ と有意な関係を認めなかった。縦軸の上 方に向かうほど視力が悪くなる。

かった。（図 5、 $\mathrm{P}=0.35 ）$

\section{IV 。考按}

小数視力と $\log M A R の$ 検査の結果は必ずしも 一致しないことが報告されているが、本研究で は、加歯黄斑変性症の視力評価としての有用性 を考察した。前提として、両検査の条件をそろ えて評価する必要がある。加齢黄斑変性症は、 黄斑部の障害により中心視力の直接的な低下を 招く疾患である。よって、字ひとつ検査は患者

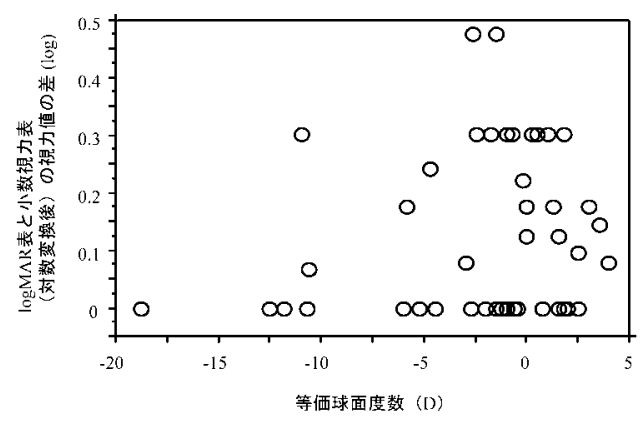

図 5 等価球面度数と視力測定結果の差との相関関 係

小数視力表の $\log$ MAR換算值と $\log M A R$ 表で得 た $\log$ MAR值との差を算出し、等価球面度数と の相関関係の評価をピアソンの相関解析にて 行った。 $\mathrm{P}=0.35$ と有意な関係を認めなかった。 縦軸の上方に向かうほど視力が悪くなる。

が視標を追う際に、一定の困難を伴う可能性が ある。我々が本研究で用いた $\log M A R$ 表は、横 一列で並んだ視標の両端が点灯する仕組みであ り、字ひとつ検査ではない。同様の条件とすべ く、小数視力表の視標の表示も横一列に点灯し て行った。 logMARは0.1から0.2の間に0.13と0.16 の視標が、0.2から0.3の間に0.25の視標があり、 低視力において小数視力表と比べてょり細分化 されている。例えば、ある患者がlogMARの0.16 を判別でき、小数視力では 0.1 までし判別でき なかったとしても、0.2の視標が判別できなけれ ばlogMARの方が視力がより良く判定されたこ とには当然ならない。両検査の条件を一定とす るため、このような場合は $\log M A R の$ 值は0.1と して扱った。本報告の結果においては、このよ うな調整を行った上で解析した。

本研究の結果から、視力がよいほど両検査の 結果に差が出やすいことが明らかとなった。こ れは過去の滝本らの報告と一致するが ${ }^{3)} 、$ 彼ら の報告では加齢黄斑変性の症例を含んでいない。 よって、視力が比較的よいほど両検査の結果に 差が出やすいのは、この疾患の特異性ではなく、 視標間隔が視標サイズに応じて狭くなるという $\log \mathrm{MAR}$ 表の視標の配列の特徵から考えて、字 づまり効果によるものと考えられる。 $\log \mathrm{MAR}$ 表には本報告で用いたものと異なり、小数視力 表のように小さい視標でも等間隔のものもある が、これらの機種を用いた場合、今回とは異な 
つた結果が得られる場合も考えられる。本報告 で用いた視力表のように、各段階の大きさの視 標を、数行にわたり同時に提示する方法で測定 する視力は字づまり視力と呼ばれている ${ }^{6)}$ 。こ の視力は、視角の值のみでなく、後頭葉の視覚 領の総合的関与が大きいので、皮質視力と呼ば れている ${ }^{6)}$ 。

$\log \mathrm{MAR}$ 表を用いた場合、字づまり効果が小児 において強く出ることが報告されているが7),8), 9)、 成人に怙ける報告例も見られる ${ }^{10), 11}$ 。我々の対 象は高齢者であるが、回帰解析の結果、年齢と 両検査の視力值の差との間に相関関係は認めな かった。加齢による認知力の低下については今 後検討する必要があるが、読みわけ困難の関与 は低いと考えられる。実際、健常高齢者におけ る読み分け困難を否定する報告も見られる ${ }^{12)}$ 。 また、等価球面度数も要因として同定されなか った (図 5 )。屈折の度数が認識される視標の 大きさに影響を及ぼす可能性があるが、これも、 両検査の結果の差の要因とはならなかったと考 えられる。本研究では高度の白内障の症例は除 外した。ただし、水晶体の混濁が軽度であった としても、白内障によるコントラスト感度の低 下が両検査の結果に影響を及ぼす可能性も否定 はできない。小数視力表で $0.1 か ゙$ 見えた場合は全 て $\log$ MAR表でも0.1が正答でき、両検査の間に 差が生じなかった。いずれの検査においても 0.1 の視標の間隔がほぼ等しいことを考慮に入れて も、再検査の視力值に差が生じた要因は字づま り効果によるものであることが示唆される。

我々の結果は、小数視力表を用いて小数視力 值を測定し換算した $\log M A R$ 值と、 logMAR表 を用いた $\log M A R$ 值とを同列に評価することの 危険性を示唆している。加齢黄斑変性症により 視力は著しく障害されロービジョンに陥りやす い。またPDTや抗VEGF療法により著しい視力 改善が得られる事もあるが、現状維持もしくは 僅かな視力改善に留まるとなる場合が多い4。 それだけに、低い視力においてより細分化され ている点で、 $\log M A R$ 表は加齢黄斑変性の視機 能の判定において有用と考えられる。ただし、 本研究結果が示す通り、比較的良好な視力にお いて小数視力表と $\log M A R$ 表との結果に差が出
やすいことは、日常の診療において注意すべき 点と思われる。

\section{参考文献}

1) Bailey IL, Lovie JE : New design principles for visual acuity letter charts : Am J Optom Physiol Opt $53: 740-745,1976$.

2 ) Stewart C: Comparison of Snellen and logbased acuity scores for school-aged children : Br. Orthopt J $57: 32-38,2000$.

3 ) 滝本正子、李 俊哉、梁島謙次、林 弘美、 菅野和子、武居佐恵、久保明夫：Bailey式の 対数視力表と従来の小数視力表とを用いて評 価した対数視力表の差異について. 眼紀51： 1153-1156, 2000.

4) Schmidt-Erfurth UM, Pruente C : Management of neovascular age related macular degeneration : Prog Retin Eye Res 26 : 437-451, 2007.

5 ) Chylack, LT, Jr, Wolfe, JK, Singer, DM, Leske MC, Bullimore MA, Bailey IL, Friend J, McCarthy D, Wu SY : The Lens Opacities Classification System III : Arch Ophthalmol $111: 831-836,1993$.

6 ) 丸尾敏夫、粟屋 忍 (編) : 視能矯正学. 214, 金原出版、東京, 1998 .

7 ) 辛 米子、尾林敦子、佐藤弘美、根本由佳、 千葉桂三 : 斜視や弱視の読み分け困難. 臨床 眼科医報 $88: 1099-1104,1994$.

8 ) Stuart JA, Burian HM : A study of separation difficulty : Am J Ophthalmol $53: 471-477$, 1962.

9 ) 桑原留美子、森由美子、調 廣子、石橋一樹、 関谷善文、山本 節：小児に扔ける $\log M A R$ 視力評価. 臨床眼科医報 $96: 40-42,2002$.

10）内海 隆：視力の臨床 1 視力表のこれまで と将来. 神経眼科 $18: 265-271,2001$.

11）昌原英隆、後藤浩也、前田直之、不二門 尚： $\log M A R$ 視力における字ひとつ視力と字 詰まり視力の比較. 視覚の科学 $24: 21-24$, 2003. 